\title{
Front Matter: Volume 7159
}

, "Front Matter: Volume 7159," Proc. SPIE 7159, 2008 International Conference on Optical Instruments and Technology: MEMS/NEMS Technology and Applications, 715901 (2 February 2009); doi: 10.1117/12.819867

SDIE Event: International Conference of Optical Instrument and Technology, 2008, Beijing, China 


\title{
PROCEEDINGS OF SPIE
}

\section{International Conference on Optical Instruments and Technology \\ MEMS/NEMS Technology and Applications}

\author{
Zhaoying Zhou \\ Shanhong Xia \\ Chih-Ming Ho \\ Helmut Seidel \\ Editors
}

16-19 November 2008

Beijing, China

Sponsored by

CIS-China Instrument and Control Society

SPIE

Cooperating Organizations

Optoelectronic-Mechanic Technology and System Integration Chapter, CIS (China) • Beijing Institute of Technology (China) • Capital Normal University (China) • Optical Instrument Chapter, CIS (China) Hamamatsu Photonics K.K. (Japan) • University of Shanghai for Science and Technology (China)

Tsinghua University (China) • Tianjin University (China) • Zhejiang University (China) • Nanjing University (China) • Chongaing University (China)

Supporting Organizations

China Association for Science and Technology • National Natural Science Foundation of China COS—Chinese Optical Society • CNCS—Chinese National Committee for SPIE

Published by

SPIE

Volume 7159 
The papers included in this volume were part of the technical conference cited on the cover and title page. Papers were selected and subject to review by the editors and conference program committee. Some conference presentations may not be available for publication. The papers published in these proceedings reflect the work and thoughts of the authors and are published herein as submitted. The publisher is not responsible for the validity of the information or for any outcomes resulting from reliance thereon.

Please use the following format to cite material from this book:

Author(s), "Title of Paper," in 2008 International Conference on Optical Instruments and Technology: MEMS/NEMS Technology and Applications, edited by Zhaoying Zhou, Shanhong Xia, Chih-Ming Ho, Helmut Seidel, Proceedings of SPIE Vol. 7159 (SPIE, Bellingham, WA, 2009) Article CID Number.

ISSN 0277-786X

ISBN 9780819474032

Published by

SPIE

P.O. Box 10, Bellingham, Washington $98227-0010$ USA

Telephone +1 3606763290 (Pacific Time) · Fax +1 3606471445

SPIE.org

Copyright (C) 2009, Society of Photo-Optical Instrumentation Engineers

Copying of material in this book for internal or personal use, or for the internal or personal use of specific clients, beyond the fair use provisions granted by the U.S. Copyright Law is authorized by SPIE subject to payment of copying fees. The Transactional Reporting Service base fee for this volume is $\$ 18.00$ per article (or portion thereof), which should be paid directly to the Copyright Clearance Center (CCC), 222 Rosewood Drive, Danvers, MA 01923. Payment may also be made electronically through CCC Online at copyright.com. Other copying for republication, resale, advertising or promotion, or any form of systematic or multiple reproduction of any material in this book is prohibited except with permission in writing from the publisher. The CCC fee code is 0277-786X/09/\$18.00.

Printed in the United States of America.

Publication of record for individual papers is online in the SPIE Digital Library.

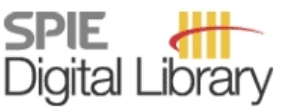

SPIEDigitalLibrary.org

Paper Numbering: Proceedings of SPIE follow an e-First publication model, with papers published first online and then in print and on CD-ROM. Papers are published as they are submitted and meet publication criteria. A unique, consistent, permanent citation identifier (CID) number is assigned to each article at the time of the first publication. Utilization of CIDs allows articles to be fully citable as soon they are published online, and connects the same identifier to all online, print, and electronic versions of the publication. SPIE uses a six-digit CID article numbering system in which:

- The first four digits correspond to the SPIE volume number.

- The last two digits indicate publication order within the volume using a Base 36 numbering system employing both numerals and letters. These two-number sets start with 00, 01, 02, 03, 04 , 05, 06, 07, 08, 09, OA, OB ... 0Z, followed by 10-1Z, 20-2Z, etc.

The CID number appears on each page of the manuscript. The complete citation is used on the first page, and an abbreviated version on subsequent pages. Numbers in the index correspond to the last two digits of the six-digit CID number. 


\section{Contents}

vii Symposium Committees

ix Conference Committee

xi Introduction

\section{SESSION 1}

715902 Design and studies of a quadrupolar dielectrophoresis chip integrated with detection electrode [7159-14]

Y. Liu, Institute of Electronics (China) and Chinese Academy of Sciences Postgraduate College (China); Z. Zhao, Institute of Electronics (China); J. Xu, C. Pang, Institute of Electronics (China) and Chinese Academy of Sciences Postgraduate College (China); Z. Fang, Institute of Electronics (China); L. Du, Institute of Electronics (China) and Chinese Academy of Sciences Postgraduate College (China)

715903 Photo system based on scanning electron microscope for IC chip inspection [7159-01] W. Liu, J. Shen, B. Tan, Shandong Univ. of Technology (China)

715904 The study of image inpainting for infrared imaging system based on micro-cantilever FPA [7159-05]

C. Gong, M. Hui, L. Dong, X. Liu, Y. Zhao, Beijing Institute of Technology (China)

715905 Optimization of a novel structure for micromachined resonant pressure sensor [7159-27] X. Shi, D. Chen, J. Wang, Z. Wu, Institute of Electronics (China)

\section{SESSION 2}

715907 A single cell penetration system by ultrasonic driving [7159-09]

Z. Zhou, Tsinghua Univ. (China); M. Xiao, X. Yang, Tsinghua Univ. (China) and State Key Lab. of Transducer Technology (China); T. Wu, China Univ. of Geosciences (China)

715908 A micro hemoglobin-A1c immunosensor based on FET and electrochemical growth of gold nanoparticles [7159-23]

L. Qu, Institute of Electronics (China) and Graduate Univ. of Chinese Academy of Sciences (China); C. Bian, Institute of Electronics (China); J. Sun, Institute of Electronics (China) and Graduate Univ. of Chinese Academy of Sciences (China); J. Han, S. Xia, Institute of Electronics (China)

7159 OA Micro amperometric immunosensor for the detection of salmonella typhimurium [7159-22] J. Sun, Institute of Electronics (China) and Graduate Univ. of the Chinese Academy of Sciences (China); S. Xia, C. Bian, Institute of Electronics (China); L. Qu, Institute of Electronics (China) and Graduate Univ. of the Chinese Academy of Sciences (China) 
SESSION 3

7159 OC A novel resonant pressure sensor with boron diffused silicon resonator [7159-34]

J. Wang, X. Shi, L. Liu, Z. Wu, D. Chen, Institute of Electronics (China); J. Zhao, S. Li, North

China Electric Power Univ. (China)

7159 OD The design and analysis of a robust micro-machined vibrating ring gyroscope [7159-32]

L. Chen, D. Chen, J. Wang, Institute of Electronics (China)

7159 OE Studies on dielectrophoretic separation using biochips with different electrode shapes [7159-15]

Y. Liu, Institute of Electronics, (China) and Graduate School of Chinese Academy of Sciences (China); Z. Zhao, Institute of Electronics (China); J. Xu, C. Pang, Institute of Electronics (China) and Graduate School of Chinese Academy of Sciences (China); Z. Fang, Institute of Electronics (China); L. Du, Institute of Electronics (China) and Graduate School of Chinese Academy of Sciences (China)

7159 OF Fast matching location algorithm based on mixed moment for wire bonding [7159-13] F. Kong, Harbin Engineering Univ. (China) and Tianjin Univ. of Science and Technology (China); X. Zhang, Harbin Engineering Univ. (China); Y. Wang, Tianjin Univ. of Science and Technology (China); D. Zhang, J. Li, Tianjin Univ. (China)

\section{POSTER SESSION}

7159 0G Design of a self-adaptive fuzzy PID controller for piezoelectric ceramics micro-displacement system [7159-02]

S. Zhang, Y. Zhong, Z. Xu, Hubei Univ. of Technology (China) and The Key Lab. of Modern Manufacturing Quantity Engineering (China)

$7159 \mathrm{OH} \quad$ Dynamic analysis of piezoelectric-solid-liquid coupled system of micro nebulizer [7159-03] M. Yang, Z. Zhou, Tsinghua Univ. (China)

7159 0I Finite element analysis of the RF MEMS switch [7159-04]

F. Zhao, Beijing Technology and Business Univ. (China); P. Wang, Beijing Institute of Technology (China); Y. Gong, L. Lv, Z. Lei, Beijing Technology and Business Univ. (China)

$71590 \mathrm{~J} \quad$ Characteristic analysis and study of an active matrix addressing for grating light modulator [7159-11]

Z. Jin, S. Huang, Z. Zhang, N. Wang, W. Wei, J. Zhang, Chongqing Univ. (China)

7159 OK High aspect ratio grating fabrication in SU-8 resist by UV-curing nanoimprint [7159-12] X. Wang, Hefei Univ. of Technology (China); L. Ge, Univ. of Science and Technology of China (China); J. Lu, Hefei Univ. of Technology (China); S. Fu, Univ. of Science and Technology of China (China)

$7159 \mathrm{OL} \quad$ The effective image denoising method for MEMS based IR image arrays [7159-17] L. Dong, X. Liu, Y. Zhao, M. Liu, M. Hui, X. Zhou, Beijing Institute of Technology (China)

7159 OM Experimental study of roof filling rate during thermal bonding of polymer microchannel sealing [7159-18]

X. Wang, J. Lu, Y. Jiang, Hefei Univ. of Technology (China); L. Ge, S. Fu, Univ. of Science and Technology of China (China) 
$7159 \mathrm{ON}$ Analysis of a Hadamard transform near-infrared spectrometer based on grating light modulator [7159-24]

W. Wei, S. Huang, Education Ministry of China (China) and Chongqing Univ. (China); Y. Zhu, Education Ministry of China (China); N. Wang, J. Zhang, Z. Jin, Education Ministry of China (China) and Chongqing Univ. (China)

715900 Design of the subwavelength dual-layer metallic nanowire-grid polarizer [7159-26]

Y. Zhou, Y. Ye, S. Shen, D. Pu, L. Chen, Soochow Univ. (China)

7159 OP Study on clamped-clamped beam in-plane capacitive resonators [7159-39]

Y. Jin, Peking Univ. (China) and Beijing Institute of Technology (China); Y. Tang, X. Yu, Peking Univ. (China)

$71590 Q \quad$ Fabrication of 1-dimension nano-material-based device and its electrical characteristics [7159-40]

$X$. Yang, Tsinghua Univ. (China) and State Key Lab. of Transducer Technology (China);

Z. Zhou, F. Zheng, M. Zhang, Tsinghua Univ. (China)

7159 OS Coupled analysis on the micro-airflow and its actuator for MEMS fluidic devices [7159-44] L. Li, Shanghai Univ. of Electric Power (China); R. Zhu, Z. Zhou, Tsinghua Univ. (China); J. Ren, Shanghai Univ. of Electric Power (China)

7159 0X Experiment on microstructure fabrication with UV-LIGA technology [7159-30]

$X$. Zheng, Huaiyin Institute of Technology (China) and Nanjing Univ. of Aeronautics and Astronautics (China)

Author Index 
Downloaded From: https://www.spiedigitallibrary.org/conference-proceedings-of-spie on 25 Apr 2023

Terms of Use: https://www.spiedigitallibrary.org/terms-of-use 


\title{
Symposium Committees
}

\author{
General Chairs \\ Songlin Zhuang, Shanghai University of Science and Technology \\ (China) \\ Kevin Harding, GE Global Research (United States) \\ General Cochairs \\ Yuri Chugu, New Siberia Academy of Sciences (Russian Federation) \\ Pochi Yeh, University of California, Santa Barbara (United States) \\ Honorary Chairs \\ Daheng Wang, Chinese Academy of Sciences (China) \\ T. Hiruma, Hamamatsu Photonics K. K. (Japan) \\ Guoguang Mu, Nankai University (China) \\ Bingkun Zhou, Tsinghua University (China) \\ Technical Program Chair
}

Guofan Jin, Tsinghua University (China)

Technical Program Cochairs

Yimo Zhang, Tianjin University (China)

Shanglian Huang, Chongqing University (China)

Local Organizing Committee Chair

Youhua Wu, China Instrument and Control Society (China)

Local Organizing Committee Cochairs

Guoqiang Ni, Beijing Institute of Technology (China)

Daoyin Yu, Tianjin University (China)

Yulin Xi, Beijing Hamamatsu Photon Techniques Inc. (China)

General Secretary

Youhua Wu, China Instrument and Control Society (China) 
Administrative Vice General Secretary

Boyu Ding, Beijing Institute of Technology (China)

Vice General Secretaries

Xiongwen Qin, China Instrument and Control Society (China)

Yuejin Zhao, Beijing Institute of Technology (China)

Tiegen Liu, Tianjin University (China)

Qionghui Feng, Shanghai University of Science and Technology (China)

Cunlin Zhang, Capital Normal University (China)

Local Organizing Committee

Weimin Chen, Chongqing University (China)

Hongda Chen, Institute of Semiconductors, CAS (China)

Yan Zhang, Capital Normal University (China)

Shangzhong Jin, Chinese Jiliang University (China) 


\title{
Conference Committee
}

\author{
Conference Chairs
}

Zhaoying Zhou, Tsinghua University (China)

Shanhong Xia, Institute of Electronics (China)

Chih-Ming Ho, University of California, Los Angeles (United States)

Helmut Seidel, Saarland University (Germany)

\section{Program Committee}

Xinxin Li, Shanghai Institute of Microsystem and Information

Technology (China)

Haixia Zhang, Peking University (China)

Yang Zhao, MEMSIC Inc. (China)

Liwei Lin, University of California, Berkeley (United States)

Xing Yang, Tsinghua University (China)

Roger T. Howe, Stanford University (United States)

Isao Shimoyama, University of Tokyo (Japan)

Aiqun Liu, Nanyang Technological University (Singapore)

Man Wong, The Hong Kong University of Science \& Technology (China)

Longsheng Fan, National Tsinghua University (China) 
Downloaded From: https://www.spiedigitallibrary.org/conference-proceedings-of-spie on 25 Apr 2023

Terms of Use: https://www.spiedigitallibrary.org/terms-of-use 


\section{Introduction}

Collected over five volumes are the accepted papers from the International Conference on Optical Instruments and Technology 2008 (OIT'08). It is truly a great pleasure for me that the most recent progress in optical instrumentation technology is involved in the OIT'08 proceedings. I firmly believe that the papers included in these OIT'08 proceedings volumes will provide reference information in up-to-date techniques of optical instrumentation technology.

The International Conference on Optical Instruments and Technology 2008 (OIT'08) was sponsored by China Instrument and Control Society (CIS) and was cosponsored by SPIE. The academic and engineering activities of CIS included the fields of optical instruments, control and measurement, automatic sensor, device and instruments, MEMS/NEMS technology, auto-inspection engineering, and scientific instrumentation. CIS has experienced its developments for more than 20 years. Now $\mathrm{CIS}$ has more than 30 branches to cover the related instrument domain and the MICONEX international exhibition has its excellent reputation in high quality. SPIE has given great support to organize this international conference by collaborating with us in the whole organizing process from paper collection to the proceedings publication.

The OlT'08 conference collected over 500 papers from different countries or areas of the world. Over 900 authors came from more than 10 countries, including Canada, Japan, India, Romania, Russia, Singapore, Taiwan (China), USA, Pakistan, Spain and China. Published in these five volumes of the Proceedings of SPIE are close to 400 papers. The technical field of the presented papers at the conference covers a lot of current advanced technologies. The cutting-edge technologies and applications of optical instruments were discussed. Quite a few invited papers gave exciting achievements in the fields of optical instrument technology. It is evident that the OIT'08 conference has provided an excellent platform for participants and colleagues in research and development to share the technical progress and to develop new partnerships or broaden new markets.

Finally, on behalf of CIS and conference general chairs, l'd like to heartily thank our supporters and committee members for all they have done for this meeting. Thanks also go to all authors for their contributions; to all of the participants and friends for their interest, especially those who have traveled great distances and taken their time from their busy schedules to attend the meeting. I am also grateful to the staff of SPIE for their support and collaboration in publishing these volumes.

Zhuang Songlin

Chairman, China Instrument and Control Society 
Downloaded From: https://www.spiedigitallibrary.org/conference-proceedings-of-spie on 25 Apr 2023

Terms of Use: https://www.spiedigitallibrary.org/terms-of-use 